September 1998 • NREL/CP-520-25411

CONF-980935--

\title{
PV Cell and Module Performance Measurement Capabilities at NREL
}

\section{RECEIVED \\ OCT 051998 \\ OSTI}

S. Rummel, K. Emery, H. Field, T. Moriarty, A. Anderberg, D. Dunlavy, and L. Ottoson

Presented at the National Center for

Photovoltaics Program Review Meeting, September 8-11, 1998, Denver, Colorado

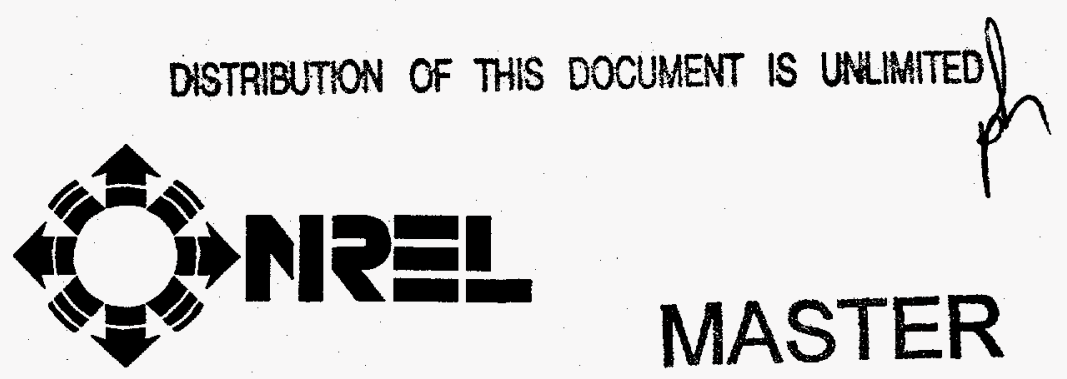

National Renewable Energy Laboratory 1617 Cole Boulevard Golden, Colorado 80401-3393

A national laboratory of the U.S. Department of Energy Managed by Midwest Research Institute for the U.S. Department of Energy under Contract No. DE-AC36-83CH10093

Prepared under Task No. PV803401

September 1998 


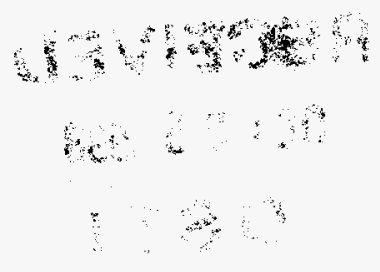

\section{NOTICE}

This report was prepared as an account of work sponsored by an agency of the United States government. Neither the United States government nor any agency thereof, nor any of their employees, makes any warranty, express or implied, or assumes any legal liability or responsibility for the accuracy, completeness, or usefulness of any information, apparatus, product, or process disclosed, or represents that its use would not infringe privately owned rights. Reference herein to any specific commercial product, process, or service by trade name, trademark, manufacturer, or otherwise does not necessarily constitute or imply its endorsement, recommendation, or favoring by the United States govemment or any agency thereof. The views and opinions of authors expressed herein do not necessarily state or reflect those of the United States govermment or any agency thereof.

Available to DOE and DOE contractors from:

Office of Scientific and Technical Information (OSTI)

P.O. Box 62

Oak Ridge, TN 37831

Prices available by calling (423) 576-8401

Available to the public from:

National Technical Information Service (NTIS)

U.S. Department of Commerce

5285 Port Royal Road

Springfield, VA 22161

(703) $487-4650$ 


\section{DISCLAIMER}

Portions of this document may be illegible in electronic image products. Images are produced from the best available original document. 


\title{
PV Cell and Module Performance Measurement Capabilities at NREL
}

\author{
Steve Rummel, Keith Emery, Halden Field, Tom Moriarty, \\ Allan Anderberg, Don Dunlavy, and Larry Ottoson
}

National Renewable Energy Laboratory (NREL), 1617 Cole Blyd., Golden, CO, 80401

\begin{abstract}
The Photovoltaic (PV) Cell and Moduie Performance Characterization team at NREL supports the entire photovoltaic community by providing: secondary calibrations of photovoltaic cells and modules; efficiency measurements. with respect to a given set of standard reporing condicions; verification of contract efficiency milestones; and current versus voltage (I-V) measurements under various conditions of temperature, spectral irradiance, and total irradiance. Support is aiso provided to in-house programs in device fabrication, module stability, module reliability, PV systems evaluations, and altemative rating methods by performing baseline testing, specialized measurements and other assistance when required. The I-V and spectral responsivity equipment used to accomplish these tasks are described in this paper.
\end{abstract}

\section{INTRODUCTION}

Measurement of the current versus voltage (I-V) characteristics of a photovoitaic (PV) cell or module are made with respect to a set of standards [1]. Reference conditions are defined by a total irradiance, spectral irradiance, and device temperature. When a photovoltaic reference cell is used to set the light level in a solar simulator, the spectral correction factor $[1,2]$ is computed before the measurement is performed using Eq. (1) to match the response of the sample under test to the simulator:

$$
I^{T, R}=\frac{C V * E_{r e f} * I^{T, S}}{M^{*} I^{R, S}}=\frac{I^{R, R} * I^{T, S}}{M^{*} I^{R, S}}
$$

where:

$I^{T, R}=$ calibrated short-circuit current of the test cell under the reference spectral irradiance $\left(E_{\text {ref }}(\lambda)\right)$,

$I^{R . R}=$ calibrated short-circuit current of the reference cell under the reference spectral irradiance,

$I^{T, S}=$ measured short-circuit current of the test cell under the source or simulator spectrum $\left(E_{s}(\lambda)\right.$ ),

$I^{R, S}=$ calibrated short-circuit current of the reference cell under the source or simulator spectrum,

$C V=$ calibration value of the reference cell in units of current / irradiance, and

$E_{\text {ref }}=$ total irradiance.

The spectral mismatch correction factor, $M$, can be written as: 


$$
M=\frac{\int_{\lambda_{1}}^{\lambda_{2}} E_{S}(\lambda) * S_{t}(\lambda) d \lambda \int_{\lambda_{3}}^{\lambda_{4}} E_{r e f}(\lambda) * S_{r}(\lambda) d \lambda}{\int_{\lambda_{3}}^{\lambda_{3}} E_{s}(\lambda) * S_{r}(\lambda) d \hat{\lambda} \int_{\lambda_{1}}^{\lambda_{2}} E_{r e f}(\lambda) * S_{t}(\lambda) d \lambda},
$$

where:

$$
\begin{aligned}
& S_{t}(\lambda)=\text { spectral response of the test cell, and } \\
& S_{r}(\lambda)=\text { spectral response of the reference cell. }
\end{aligned}
$$

For measurements under natural sunlight, the iradiance is measured using a calibrated photovoltaic cell or a thermal detector such as a cavity radiometer or pyranometer, with the spectral correction factor computed after the measurement.

\section{SPECTRAL RESPONSIVITY MEASUREMENT SYSTEMS}

Spectral responsivity measurements have been performed at NREI on cells since 1984 [3] and more recently on modules. Spectral responsivity is the photo-current produced by a PV cell when illuminated by a light source of a given wavelength and power. The test device signal is compared to the signal from a NIST-calibrated (or NIST-traceable) reference ceil at each wavelength to determine the spectral response. To obtain the quantum efficiency (QE) of a device, the spectral responsivity is converted into the percent of electrons produced versus the photons supplied.

A filter spectral responsivity system is used to perform relative measurements from $280 \mathrm{~nm}$ to $1900 \mathrm{~nm}$. A custom current-to-voltage operational amplifier circuit with a programmable gain from 50 to 10,000 is normally used and has a current limit of 200 $\mathrm{mA}$.

A new technique to measure the spectral responsivity of a module has been developed [4]. Previous module spectral responsivity measurements at NREL involved illuminating the entire module and setting the bias to the normal zero volts. The new technique is essentially a generalization of the procedures to measure the spectral responsivity of multijunction cells. This procedure invoives setting the light bias conditions so that all cells are illuminated with broad-band light, with the cell in the module that you wish to measure having less light so that it is current-limiting. The module is forward-biased to slightly less than the open-circuit voltage of the entire module. This procedure has been successfully used for amorphous Si, CuInSe $e_{2}$, monocrystalline $\mathrm{Si}$, and $\mathrm{CdTe}$ modules.

A grating monochromator system measures the absolute spectral responsivity of a cell from $400 \mathrm{~nm}$ to $2800 \mathrm{~nm}$. A $1-\mathrm{mm}$ by $3-\mathrm{mm}$ beam is produced by a $100-\mathrm{W}$ tungsten lamp followed by filter and grating combinations, a chopper, and focusing optics. Typical entrance and exit slit combinations yield bandwidths of $10 \mathrm{~nm}$ or less. Currents for the test and reference devices are measured using a current-to-voltage preamplifier, which is then fed into a lock-in amplifier, to provide a more accurate measurement. Custom software sets filter and grating positions, lock-in parameters, and 
runs a variety of measurement checks at each wavelength. Measurement uncertainties are $\sim 2 \%$ from $500 \mathrm{~nm}$ to $950 \mathrm{~nm}$ and $\sim 4 \%$ from $950 \mathrm{~nm}$ to $1850 \mathrm{~nm}$.

A new system for measuring the spectral responsivity of solar photovoltaic devices has been developed [5]. The spectral range is $280-1330 \mathrm{~nm}$, and the bandwidth of the monochromatic beam is $-2 \mathrm{~nm}$. The light source is a xenon-arc lamp with an ellipsoidal refflector. A three-section, custom fiber-optic bundle provides monochromatic and bias light to the sample and a reference signal to a monitor cell.

The data provided by these three spectral responsivity systems supply the value $S_{t}(\lambda)$ for calculating the spectral correction factor, provide an estimate of the spectrial sensitivity, and estimate the $I_{s c}$ of a given sample.

\section{I-V DATA COLLECTION SYSTEMS}

The I-V data acquisition systems used by the PV Cell and Module Performance Team at NREL are summarized in Table 1.

Table 1. Comparison of I-V measurement systems.

\begin{tabular}{llll}
\hline $\begin{array}{l}\text { Light } \\
\text { Source }\end{array}$ & Allowed Sample Size & $\begin{array}{l}\text { Maximum } \\
\text { Voltage / Current }\end{array}$ & $\begin{array}{l}\text { Iradiance Range } \\
\text { "suns" }\end{array}$ \\
\hline X25 & $<30 \mathrm{~cm}$ by $30 \mathrm{~cm}$ & $\pm 50 \mathrm{~V} / \pm 16 \mathrm{~A}$ & 0.6 to 1.2 \\
Continuous & $<0.1$ to $4 \mathrm{~cm}^{2}$ & $\pm 10 \mathrm{~V} / \pm 10 \mathrm{~A}$ & 0.4 (for AM0) \\
Infrared & $<0.1$ to $18 \mathrm{~cm}^{2}$ & $\pm 10 \mathrm{~V} / \pm 10 \mathrm{~A}$ & 0.1 to 200 \\
HIPSS & $<10 \mathrm{~cm} \times 10 \mathrm{~cm}$ & $100 \mathrm{~V} / 50 \mathrm{~A}$ & $1-2000$ \\
LAPSS & $<2 \mathrm{~m} \times 2 \mathrm{~m}$ & $100 \mathrm{~V} / 50 \mathrm{~A}$ & $\sim 1$ \\
LACSS & $<122 \mathrm{~cm} \times 152 \mathrm{~cm}$ & $\pm 100 \mathrm{~V} / \pm 20 \mathrm{~A}$ & $\sim 1$ \\
& & $\pm 20 \mathrm{~V} / \pm 60 \mathrm{~A}$ & \\
SPIRE 240 A & $<76 \mathrm{~cm} \times 130 \mathrm{~cm}$ & $\pm 100 \mathrm{~V} / 12 \mathrm{~A}$ & $0.15-1.3$ \\
SOMS & & $\pm 100 \mathrm{~V} / \pm 20 \mathrm{~A}$ & Natural sunlight \\
& & $\pm 20 \mathrm{~V} / \pm 60 \mathrm{~A}$ & \\
Daystar DS-10/125 & $\begin{array}{l} \pm 300 \mathrm{~V} / \pm 4 \mathrm{~A} \\
600 \mathrm{~V} / 125 \mathrm{~A}\end{array}$ & Natural sunlight
\end{tabular}

\section{Solar Simulators}

The Spectrolab X25 solar simulator has provided reliable measurements on PV cells for many years [6], currently providing over 40 measurements a month. Its $3-\mathrm{kW}$ xenon-arc source is fiitered with optical elements to resemble the AM1.5 Global spectrum (ASTM E927 class A). Spatial uniformity of $\pm 3 \%$, at one sun, is attainable over the area of the vacuum plate $(30 \mathrm{~cm}$ by $30 \mathrm{~cm})$. Uniform sample temperature of $\pm 1^{\circ} \mathrm{C}$ is attained over the range from $5^{\circ}-50^{\circ} \mathrm{C}$ with the use of this plate. The irradiance is adjustable from 0.2 to 20 suns with decreased sample size and spatial uniformity. One modification to the X25 has been a custom attachment of up to 19 separate, individually adjustable filters to modify the spectrum. This provides the capability to set the current for each junction in a multijunction cell or module to the proper level. A custom data 
acquisition system allows for access to the data and ease of future modifications. The system is also used for low-level concentrator cell and dark I-V measurements ( $>10 \mathrm{pA})$.

The continuous-illumination concentrator system is adjustable from 0.1 to 200 suns. A $1-\mathrm{kW}$ Xe short-arc source through focusing optics yields a beam diameter from 0.1 $\mathrm{cm}$ to $4 \mathrm{~cm}$. The "Fast V" method [7] is used to set cell temperature. Aiternatively, a 7$\mathrm{kW}$ tungsten infrared lamp without focusing optics may be used for thermophotovoltaic devices. Because of the high-intensity light, large temperature gradients exist between the temperature-controlled plate and the device space-charge region. The bias power supply and voltmeters are controlled by custom software. Voltage and current uncertainties are less than $\pm 1 \mathrm{mV}$ and $\pm 10 \mu \mathrm{A}$, respectively.

The Large-Area Continuous Solar Simulator (LACSS) measurement system, manufactured by Spectrolab Inc., has a continuous $20-\mathrm{kW}$ xenon short-arc lamp with a water-cooled collector, with integration optics and filters to provide a close match to the AM1.5 Global spectrum. It is housed in a special room to permit samples as large as $122 \mathrm{~cm}$ by $152 \mathrm{~cm}$ to be measured, with spatial uniformity of $+3 \%$. A special test bed was designed and installed for improved mounting and temperature measurement of the samples. Custom software controls the data acquisition system, enabling the system to perform dark I-V measurements on modules, as well as ensure compatibility with other systems within the team. This system enhances the capability to evaluate modules that are sensitive to pre-measurement conditions, bias rate, or bias direction [8].

The Large-Area Pulsed Solar Simulator (Spectrolab Inc.'s LAPSS II) can measure samples in size up to $2 \mathrm{~m}$ by $2 \mathrm{~m}$, which is limited by the room size. This model is used extensively by the aerospace community. The system incorporates a lamp housing, a pulse-forming network, and a data acquisition system. The light source is two xenon long-arc lamps $(1-3 \mathrm{kV})$ that delivers a pulse for $1 \mathrm{~ms}$ with a spatial uniformity of $\pm 2 \%$ over the test bed. The test bed was custom made and matches the one for the LACSS. A new custom temperature-controlled test bed, currently being assembled for use with LAPSS and LACSS, will enable us to make I-V measurements over the temperature range of $15^{\circ}$ to $75^{\circ} \mathrm{C}$, with improved temperature coefficient measurements as a result. The large distance $(10 \mathrm{~m})$ between the test bed and lamps allows for the spectrum to be modified by filtering a portion of the light with colored glass for multijunction modules.

The High-Intensity Puised Solar Simulator (HIPSS), which is also manufactured by Spectrolab Inc., is used to measure I-V characteristics of cells used for solar concentrator and thermophotovoltaic applications. The system is a high-intensity lamp housing that uses the same pulse-forming network and data acquisition system ased with the LAPSS. The light source is the same as the LAPSS, but with parabolic mirrors. This system is capable of delivering up to a 2000-sun pulse of light, with a spatial uniformity within $2 \%$ over a $10-\mathrm{cm}$ by $10-\mathrm{cm}$ temperature-controlled vacuum plate for about $1 \mathrm{~ms}$. Because this is a flash simulator, the sample temperature change is negligible during the test. The data acquisition system is controlled by software developed by NREL. With future enhancements, the spectrum can be modified, with the spatial uniformity being maintained, by placing filters close to the bulb.

SPIRE solar simulators are commonly used by the terrestrial PV community because of their cost and ease of use. Module measurements at NREL are performed on a model \#240A whenever possible to compare data with customers using the same model. It has been used at NREL for the past 15 years and provides in excess of 100 measurements per month. The unit incorporates a long-arc pulsed xenon lamp as its light source, which is flashed at a rate of up to $15 \mathrm{~Hz}$ and is filtered to resemble the global reference spectrum. During each pulse, a data point is taken for a total of more than two hundred points of data per sample. The span of irradiance is 0.5 to 1.3 suns. Screen filters are used to extend the intensity range down from 0.5 to 0.15 suns, when needed. The 
spatial uniformity is $\pm 3 \%$ over an area of $76 \mathrm{~cm}$ by $130 \mathrm{~cm}$. Temperanure measurements are made with a spring-loaded, type $\mathrm{K}$ thermocouple making contact with the back of the sample. Procedures have been developed to calibrate the permanently mounted reference cell using cells or modules that are calibrated by other systems. A removable heating blanket is used in making temperature-coefficient measurements [9]. The original software has been modified for improved data analysis and retrieval, as well as for improved data presentation. This system produces errors in the value for fill factor and maximum power on some thin-film material samples due to its flash rate and the sample's response time [\$].

\section{Outdoor Systems}

The Standard Outdoor Measurement System (SOMS) provides the capability to perform I-V measurements outdoors under natural sunlight. Normally, these measurements are periormed under clear-sky conditions between 950 and $1050 \mathrm{~W} / \mathrm{m}^{2}$ and as close to $25^{\circ} \mathrm{C}$ ambient temperarure as possible. The sample is mounted to a custom test bed that can be rotated or tilted to any position. Temperature measurements can be made with thermocouples or resistance temperamure detectors, usually making contact with the back surface of the sample. To ensure that samples are not light-soaked or being annealed, the exposure time of the sample is kept to a minimum ( $<5$ minutes). Because of this quick "snap-shot" approach, the PV junction temperature is not at an equilibrium condition during the measurement. The total irradiance is measured using a calibrated PV silicon cell in a module package, as well as a pyranometer. The spectral irradiance is measured during the test using a modified LICOR LI-1800 temperaturecontrolled spectroradiometer. Meteorological data are measured and recorded during the measurement.

The Daystar DS-10/125 Portable I-V Curve Tracer gives us with the capability of going to the sample and measuring it in situ. The total irradiance is measured using a pyranometer mounted in the same plane as the sample.

\section{Primary Reference Cell Calibration Facility}

Primary reference cells used at NREL are calibrated using the most accurate instrumentation available [3]. Procedures and equipment were chosen to minimize error sources and provide direct traceability to the world radiometric reference scale. This system has been qualified as one of the four primary reference-cell calibration facilities in the world for the world photovoltaic scale [10]. This scale is an intemationally accepted calibrated reference cell that is suitable for module accreditation and certification programs such as the PV Global Accreditarion Program (PVGAP). Intercomparisons and uncertainty analysis show that the primary calibration uncertainty is approximately $\pm 1 \%$.

\section{SUMMARY}

Efficiency measurements for PV cells and modules are prone to unusual and anomalous behavior, including short-term and long-term instabilities of a reversible and irreversible nature. Other artifacts are related to the high capacitance or low thermal conductivity of the PV device. This team strives to identify these effects and alert the PV community to procedures or equipment that may mitigate these effects. With devices constantly changing, the equipment has been designed with flexibility in mind, so even 
if a device parameter is outside the list in Table 1, there is a good chance the equipment can be modified to handle it. Future activities will include enhancing existing and developing new measurement systems and techniques, and continuing to provide accurate and traceable efficiency measurements. PV efficiency measurement technology is transferred on a routine basis to manufacturers, researchers, and numerous other interested parties through test reports, papers, and publications, as well as through our internet web site (www.nrel.gov/measurements/). This task will continue to be an active

participant in U.S. and intemational PV intercomparisons and consensus standards development.

\section{ACKNOWLEDGMENTS}

This work is performed under Contract No. DE-AC36-83CH10093 to the U.S. Department of Energy.

\section{REFERENCES}

1. "Standard Test Methods for Electrical Performance of Nonconcentrator Terrestrial Photovoltaic Modules and Arrays Using Reference Cells," ASTM Standard E1036M-96, 1997 (American Society for Testing and Materials, 100 Barr Harbor Drive, West Conshohocken, PA).

2. K.A. Emery, et al. "Methods for Measuring Solar Cell Efficiency Independent of Reference Cell or Light Source," Proceedings of the 18th IEEE Photovoltaic Spec. Conf., Las Vegas, NV, October 21-25, 1985, pp. 623-628, IEEE, New York, 1985.

3. C.R. Osterwald, et al. "Primary Reference Cell Calibrations at SERI: History and Methods," Proceedings of the 21th IEEE Photovoltaic Specialists Conf., Orlando, FL, May 21-25, 1990, pp.1062-1067, IEEE, New York, 1990.

4. K. Emery, D. Dunlavy, H. Field, and T. Moriarty, "Photovoltaic Spectral Responsivity Measurements," Proceedings of the 2nd World Conference and Exhibition on Photovoltaic Solar Energy Conversion, Vienna, Austria, July 6-10, 1998.

5. H. Field, "UV-VIS-NIR, Spectral Responsivity Measurement System for Solar Cells," Proceedings of the 14th NREL / Sandia Program Review Meeting, Lakewood, CO, September 8-11, 1998.

6. K.A. Emery and C.R. Osterwald, "Solar Cell Efficiency Measurements," Solar Ceils, 17, 253-274 (1986).

7. T. Moriarty and K. Emery, "Thermophotovoltaic Cell Temperature Measurement Issues," Proc. $4^{\text {th }}$ NREL Thermophotovoltaic Generation of Electricity Conference, October 11-14, 1998, Denver, CO.

8. K. Emery and H. Field, "Artificial Enhancements and Reductions in the PV Efficiency," Proceedings of the 24th IEEE Photovoltaic Specialists Conf., Waikoloa, HI, December 5 -9, 1994, pp. 1833-1838, IEEE, New York, 1994.

9. K. Emery, et al. "Temperature Dependence of Photovoltaic Cells, Modules, and Systems," Proceedings of the 25th IEEE Photovoltaic Specialists Conf., Washington D.C., May 13-17, 1996, pp. 741-744, IEEE, New York, 1996.

10. C.R. Osterwald, et al. "Resuits of the PEP'93 Intercompairson of Reference Ceil Calibrations and Newer Technology Performance Measurements," Proceedings of the 25th IEEE Photovoltaic Specialists Conf., Washington D.C., May 13-17, 1996, pp. 1263-1266, IEEE, New York, 1996. 